\title{
Multinational enterprises, European state aid and transfer pricing
}

Citation for published version (APA):

Szotek - Ververken, P. (2020). Multinational enterprises, European state aid and transfer pricing: a study of the application of EU State Aid Law to transfer pricing and allocation of income to permanent establishments. [Doctoral Thesis, Maastricht University]. Maastricht University. https://doi.org/10.26481/dis.20201204ps

Document status and date:

Published: 01/01/2020

DOI:

$10.26481 /$ dis.20201204ps

Document Version:

Publisher's PDF, also known as Version of record

\section{Please check the document version of this publication:}

- A submitted manuscript is the version of the article upon submission and before peer-review. There can be important differences between the submitted version and the official published version of record.

People interested in the research are advised to contact the author for the final version of the publication, or visit the DOI to the publisher's website.

- The final author version and the galley proof are versions of the publication after peer review.

- The final published version features the final layout of the paper including the volume, issue and page numbers.

Link to publication

\footnotetext{
General rights rights.

- You may freely distribute the URL identifying the publication in the public portal. please follow below link for the End User Agreement:

www.umlib.nl/taverne-license

Take down policy

If you believe that this document breaches copyright please contact us at:

repository@maastrichtuniversity.nl

providing details and we will investigate your claim.
}

Copyright and moral rights for the publications made accessible in the public portal are retained by the authors and/or other copyright owners and it is a condition of accessing publications that users recognise and abide by the legal requirements associated with these

- Users may download and print one copy of any publication from the public portal for the purpose of private study or research.

- You may not further distribute the material or use it for any profit-making activity or commercial gain

If the publication is distributed under the terms of Article $25 \mathrm{fa}$ of the Dutch Copyright Act, indicated by the "Taverne" license above, 
Propositions relating to the dissertation

\section{MULTINATIONAL ENTERPRISES, EUROPEAN STATE AID AND TRANSFER PRICING: A Study of the Application of EU State Aid Law to Transfer Pricing and Allocation of Income to Permanent Establishments}

1. Since legislative proposals on EU tax law require a special legislative procedure and an unanimous vote in the Council of the EU, the action on the part of the EC's DG COMP taken to prevent harmful tax competition and aggressive tax planning, such as intentional intra- and inter-state(s) mismatches caused by fiscal arrangements between States and MNEs to the extent they violate EU State aid rules, is laudable.

2. It is a matter of choice for the CJEU to let the assessment of the fiscal arm's length principle adhered to at national level - prevail over the examination under the arm's length tool and benchmark as established by the EC and the General Court. An affirmative answer would require the CJEU to decide that Member States are sovereign in fiscal matters and may adhere to the fiscal arm's length principle by the autonomous legislatures' choice to reinforce the corporate tax base of MNEs under their national CIT systems.

3. Abandoning the adherence to the arm's length tool and benchmark under Article 107(1) TFEU can, in certain cases, allow the DG COMP to redirect its attention to assess intra-group transactions in relation to national anti-avoidance provisions, focussing on defeating the effect of transactions that have little or no commercial reality but are intended to reduce or avoid a tax charge or to artificially create a tax deduction or a tax refund.

4. Intra-group loan arrangements and transactions relating to intangibles of an MNE are the most technical and challenging aspects of assessing income allocation under EU State aid rules due to ongoing regulatory developments and their non-uniform application across countries.

5. The OECD's efforts to tax activities that create a real value may extend beyond the arm's length principle, which is likely to be supplemented by a formulaic approach.

6. Where the conditions of the Temporary Framework for State Aid Measures to Support the Economy in the Current COVID-19 Outbreak adopted under Article 107(3)(b) TFEU are not satisfied or where the measure is not covered by this Framework, a Member State should still be able to obtain prompt EC's clearance directly under Article 107(3)(b) TFEU.

7. Allowing companies to report too much income while benefitting from R\&D\&I tax incentives such as tax credits, allowances, deferrals, and 'patent box' regimes, should not escape the attention of the DG COMP, as it can constitute State aid if all the criteria of Article 107(1) TFEU are fulfilled.

8. Whereas many have an opinion about the State aid framework used to analyse transfer pricing and income allocation rules, this research calls for increased transparency and certainty through the solutions recommended on how this framework should be changed.

9. The greatest value of travelling is that often what you see and experience on the spot is completely different from what you learn about those locations before you depart; travelling gives you the luxury of forming your own opinions.

10. Climbing brings happiness when you know that you still have a few hundred steps to reach your goal that is right in front of you; mountains are there to experience the joy of conquest in every (little) step you take. 